Accepted refereed manuscript of: Freathy P \& Calderwood E (2020) Social transformation in the Scottish islands:

Liberationist perspectives on consumer empowerment. Journal of Rural Studies, 74, pp. 180-189.

DOI: https://doi.org/10.1016/j.jrurstud.2020.01.016

(C) 2020, Elsevier. Licensed under the Creative Commons Attribution-NonCommercial-NoDerivatives 4.0 International http://creativecommons.org/licenses/by-nc-nd/4.0/

\title{
Social transformation in the Scottish islands: liberationist perspectives on consumer empowerment
}

\author{
by \\ Paul Freathy*
}

and

Eric Calderwood

Institute for Retail Studies

Stirling Management School

University of Stirling

Stirling

Scotland

FK9 4LA

j.p.freathy@stir.ac.uk

eric.calderwood@stir.ac.uk

*Contact author

This work was supported by the British Academy under Grant number SG112259 


\title{
Social transformation in the Scottish islands: liberationist perspectives on consumer empowerment
}

\begin{abstract}
Through a conceptual framework derived from 1960's Christian Liberation Theology this paper examines the impact of e-commerce upon the social transformation of spatially isolated Scottish communities. While many studies have highlighted the impact of internet adoption upon individual choice and the co-creation of value, this paper argues that such advantages are mediated by structural impediments that constrain its potentially empowering effects. Viewing e-commerce through the lens of liberation theory acknowledges the influence of the economic, political and social environment upon consumer emancipation. While empowerment remains contextually determined and reflects the desire of groups and individuals to reassert control over their own existence, established hierarchies seek to dominate the power logic and reinforce existing market inequalities.
\end{abstract}

\section{Keywords}

Empowerment

Liberation Theology

Island Retailing

E-commerce

Rural 


\section{Introduction}

The concept of empowerment has diverse origins and has previously been explored in the context of civil rights, anti-racism and gender studies (Harrison et al 2006; Lindridge et al. 2016). In addition, a number of investigations have considered the impact of employee empowerment across a range of different economic sectors including healthcare and pharmacy (Lemire 2010; Rapp et al., 2010); tourism and hospitality (Lee et al. 2016; Niinien et al., 2007) and financial services (Yoo 2017). Studies of empowerment within contemporary rural society, range from the engagement of local communities in land use planning to reassertions of social inclusion amongst minority groups (Cherayi and Jose 2016; Guirado et al., 2017; Harrison et al., 2006; McKee 2015). Perhaps because of, or despite this level of academic attention, various definitions of empowerment continue to inform empirical research.

This paper examines consumer empowerment from a human liberationist perspective. Although rooted in the post-Enlightenment theological movement that grew out of South American political struggle in the 1960s, the theory has found contemporary expression amongst those most disaffected by social and economic injustice. The recognition that inequality is perpetuated through structural market impediments is accompanied by a conviction that individuals should not remain passive or indifferent to either their own, or each other's sufferings. Although more typically applied to areas such as social work and healthcare (Allen 2008; Evans 1992), this paper will argue that the principles of liberationism has relevance to our understanding of social transformation in rural communities. 
The concept of power represents a central construct within liberationist thought. Those who hold dominant positions within an existing socio-political hierarchy, are motivated by selfinterest and a reluctance to relinquish power. Inequality is reinforced through structural market impediments that seek to maintain the asymmetry inherent within the existing power logic. Existing disparities are further reinforced through economic injustices that ensure businesses remain the dominant party in market exchange relationships (Clarke 2000). For example, while consumers may elect to choose between different sellers, switching to a different provider is often limited by choice, availability and high search costs (Clarke 2000; Steiner 1985; London Economics 1997). However, the benefits afforded by e- commerce ${ }^{1}$ would seem to not only challenge the inequities inherent within the exchange relationship, it appears to offer opportunities for wider social transformation (Christodoulides 2009; Neghina et al., 2014).

Living within an island community provides individuals with a series of unique, market based challenges that have to date, received only limited academic attention (Armstrong et al., 1991; Byrom et al., 2001, 2003; Freathy and Calderwood 2013, 2016; Marshal et al., 2018; Schiffling et al. 2015; Skerrat 1999). Traditionally, residents have had to contend high prices, poor product quality and limited availability. While goods sold in physical stores have been supplemented through other channels (such as catalogues, mobile shops and product fairs), it has been acknowledged that island communities often remain disadvantaged when it comes to the purchase of goods and services (Calderwood and Freathy 2011). The advantages afforded by e-commerce would therefore seem to represent a mechanism for empowering consumers and overcoming many of the limitations associated with island life.

\footnotetext{
${ }^{1}$ In this paper e-commerce is defined as 'commercial transactions conducted electronically on the internet' https://www.lexico.com/en/definition/e-commerce
} 
Through an examination of the impact of e-commerce upon the consumption behaviour of island residents, this paper examines whether the internet has helped redress structural market failings and challenged inherent inequalities within established power hierarchies. Moreover, by locating the study within a framework of economic and social liberation it is possible to develop a broader, more holistic theory of consumer empowerment. In so doing, the paper will explore whether the decentralisation of power and the democratisation of authority accompanying e-commerce has challenged the economic imbalances inherent within island communities.

To achieve the above aims, the paper is divided as follows; first, the applicability of Liberation Theology to the concept of consumer empowerment is discussed. This is followed by a brief overview of the practical issues of living in an island community. After the methodology is outlined, the empirical research details how the consumption process has been reconfigured and the implications of this for island residents. Finally, a discussion seeks to further our theoretical understanding of empowerment before a series of conclusions are drawn.

\section{Consumer Empowerment}

Despite being widely discussed within the academic literature, there is limited consensus over the meaning of empowerment. This may in part stem from a propensity to over simplify its meaning as well as a tendency to apply the concept to a broad range of investigative fields (Denegri-Knott et al., 2006). For example, studies that have examined empowerment within the context of employee - employer relations, associate the term with a deliberate transfer of authority. By gaining control over the employment issues that concern them, individuals 
display improvements in morale, job satisfaction and ultimately business performance (Pires et al., 2006; Simintiras et al., 2012).

Within a consumer context, definitions of empowerment have ranged from the provision of aesthetic enhancements in the shopping experience to overcoming constraints upon individual choice (Harrison et al., 2006; Niininen et al., 2007; Saren, 2011; Wright et al. 2006). Others have argued the concept is predicated upon the exercise of power and the derivation of customer sovereignty through economic leverage (Denegri-Knott 2006; Pires et al., 2006). Empowerment therefore represents an enabling process that leads to a broader transformation of existing power structures. Although it may remain inseparable from notions of control, authority and commercial exchange, this paper seeks to build upon existing conceptual models and locate empowerment within the broader framework of human liberation theory (Cherayi and Jose 2016; Gutiérrez 1988; Sherover-Marcuse 2003; Smith 1991; Waltz 2016). Rooted in the struggle for Catholic religious reform in Latin America between the 1960's and 1980's, liberation theology ${ }^{2}$ suggested that poverty should be explained through the realities of exploitation, injustice and oppression. Inequality remains the outcome of structural market impediments that place constraints upon the rights, freedoms and aspirations of individuals (Evans 1992). Social transformation becomes impossible without redressing the unequal distribution of wealth and the dominant power logic that characterises international relations.

In addition to identifying the causes of human inequity, liberation theory also recognises the various manifestations of disempowerment. A removal of the right to education, to housing and to legal representation are all factors that contribute to feelings of dependence, low self

\footnotetext{
${ }^{2}$ Initially associated with Christian social reform in parts of Latin America, the term "Liberation Theology" came to represent the experiences of the dispossessed around the world (see Evans, 1992)
} 
esteem and learned helplessness (Cherayi and Jose 2016; Evans, 1992). Change may only be engendered through a process of realisation, reflection and action (Levine, 1988). Established power hierarchies created through economic, social and political influence do not seek consensus or rely upon mutual understanding. Rather, they are governed by self-interest and seek to preserve the inequalities inherent in existing relationships. Social transformation can therefore only occur when such asymmetrical hierarchies are challenged directly. While some have drawn parallels between liberation theory and aspects of Marxist political analysis, the legacy of liberation theory has been to see social issues from the perspective of those most affected (Celis 2016; Levine, 1988). For example, the theory acknowledges that political and social injustice is most likely to occur when individuals do not have control over their own personal circumstances. Conversely, empowerment has the power to facilitate a process of inclusion and wider social transformation and occurs when individuals, communities and marginalised groups reassert control over the factors that mediate their own existence (Cherayi and Jose, 2016; Rappaport, 1987).

Liberation theory places emphasises upon an individual's economic as well as spiritual, social and political emancipation. It accepts that inequities in the exchange process may serve to limit wider social transformation. While personal choices and freedoms may be constrained by the activities of others, the realisation, reflection and action praxis inherent within liberation theory offers a means of challenging the various manifestations of economic injustice. While e-commerce has been identified as one mechanism that may contest the established power asymmetry inherent within many buyer - seller relationships, the extent to which it facilitates self-determination, remains uncertain. The competitive nature of consumer markets makes it unlikely that organisations will surrender their advantaged position either willingly or voluntarily. 
The enduring nature of established power structures means that change is primarily derived through collective action. Collectivism remains at the heart of human liberation theory and is central to the empowerment process. Initially, through analysis, individuals seek to understand the factors that account for their personal situation, these experiences are then shared with others as a means of identifying common concerns (Waltz 2016). This 'conscientization' occurs at the community level and allows individuals to reflect on their situation before developing strategies that seek to alleviate their societal position (Allen, 2008).

Within a consumer context the collective voice has aided social transformation through activities such as brand communities, networks and friendship groups (Black and Veloutsou, 2017; Schembri and Latimer, 2016). Such forums have been shown to help redress economic imbalances, safeguard rights as well as assert greater control over the negotiation process (Macdonald and Uncles, 2007; Moufahim et al., 2018; Wang et al., 2013). The notion that communities should be able to exert greater influence over their own future reflects the policy goals of the Scottish Government. Against a backdrop of rural depopulation and declining service provision, political priority has been assigned to strengthening the resilience of rural communities (Fischer and McKee 2017; McKee, 2015). For example, the 2015 Community Empowerment (Scotland) Act actively encourages the shared ownership of land and buildings, while the Islands (Scotland) Bill (2017) specifically focuses upon the mechanisms that encourage socio-economic regeneration.

The demands of the marketplace may be further resisted through lifestyle changes, alternative consumption practices as well as greater communal participation (De Bernadi and Tirabeni, 
2018). Electronic commerce represents a form of discontinuous innovation that has assisted this process and provided the opportunity for consumers to challenge existing commercial relationships (Füller et al 2009; Karimi and Walter, 2015).

Liberation theory therefore suggests a more holistic interpretation of consumer empowerment whereby structural market impediments and established power hierarchies represent barriers to wider social transformation. The indigenous nature of liberation theory however means that each environment remains unique and needs to be carefully contextualised (Evans 1992). By focusing upon the Scottish islands these spatial parameters are acknowledged.

\section{E-commerce and the Scottish Isles}

The Scottish islands are amongst the most disadvantaged and economically fragile regions of the UK (Scottish Government, 2008; 2010; Copus and Crabtree, 1992; Copus and Hopkins, 2018). This fragility is derived in part from their physical isolation and compounded by a declining population, an over reliance upon particular industries, limited employment opportunities and an inadequate transport infrastructure (Copus and Hopkins, 2018). Despite attempts to keep ferry fares competitive through the Road Equivalent Tariff. ${ }^{3}$ (RET), the Scottish Government labelled the rail network as deficient while air and sea links were identified as being expensive and subject to seasonal fluctuations (Laird and Mackie, 2009; Scottish Government, 2008).

\footnotetext{
${ }^{3}$ Road Equivalent Tariff (RET) involves setting ferry fares on the basis of the cost of traveling an equivalent distance by road. RET covers cars, coaches and small commercial vehicles up to six meters in length.
} 
These geographical and economic limitations have a number of implications for island consumers. Given that the majority of goods are delivered by sea, ferry crossings are subject to prevailing weather conditions and as a consequence both the quality and availability of products may be affected (Byrom et al., 2001, 2003; Marshall et al., 2018). In addition, the increased amount of product handling results in longer lead times and a reduction in the shelf life of many fresh items. More fundamentally, trading on an island incurs higher operational costs with transportation, fuel, staffing and waste disposal all being more expensive than on the mainland (Armstrong, et al., 1991; Freathy and Calderwood, 2016; OFT 2012). While these difficulties manifest themselves in island towns, the problems are further compounded in more remote and sparsely populated island locations (Carnegie 2007, 2008; Marshall et al., 2018; Hopkins and Copus, 2018; SAC, 2012).

Previous research has also identified a number of retail related concerns amongst island residents. A Shetland Islands report (2004) highlighted dissatisfaction with local retail provision and noted how respondents considered the local market to be expensive, offer poor quality products and provide limited levels of customer service. Similar issues were identified by Freathy and Calderwood (2013), who noted that quality standards were considered low, customer service was poor and product knowledge was limited. However, the lack of choice meant that individuals were often compelled to buy what was available at the price that was being asked. Access to the internet not only helped overcome these limitations, e-shopping ${ }^{4}$ had engendered a more profound, transformational role by allowing island residents to engage in previously unavailable socio-cultural activities.

\section{Methodology}

\footnotetext{
${ }^{4}$ In this paper e-shopping is defined as "the action or activity of buying goods or services over the internet" https://www.lexico.com/en/definition/e-shopping
} 
While there remains no agreed definition of the rural economy in Scotland (Kleinert et al., 2018), Hopkins and Copus (2018) note the criteria used to classify rural and urban areas has implications for policy and practice. For this research the Scottish Government's Urban /Rural Eight Fold Classification 2016 (Scottish Government 2018) was used. This taxonomy combines population threshold and accessibility information ${ }^{5}$ to identify both 'Very Remote Small Towns' ${ }^{6}$ and 'Very Remote Rural Areas'. ${ }^{7}$ Having only limited access to urban space, limits consumer choice by restricting the opportunity to regularly use alternative retail centres. In the context of this study, such constraints can help identify and isolate the impact that internet shopping can have upon a specific location.

\section{Figure One about here}

The research focused upon the Scottish island groups of Orkney, Shetland and the Outer Hebrides (Figure One). Each are comprised of a number of islands that vary in size, population, and level of commercial provision. For example, Lewis / Harris in the Outer Hebrides has a population of just under 20,000, is approximately 79 miles in length with an estimated drive time of two and a quarter hours. In contrast, Papa Stour in the Shetland Isles has a population of 23, just over 3 miles of tracked road and no store. Consumers therefore have different levels of access to goods and services depending upon which island they live. To identify whether this accessibility influenced consumer response, each island was first categorised according to its level of retail provision (Table One).

\footnotetext{
${ }^{5}$ Based upon drive time to an urban area.

${ }^{6}$ Very remote small towns are defined as settlements of between 3,000 and 9,999 people and with a drive time of over 60 minutes to a settlement of 10,000 or more.

${ }^{7}$ Very remote rural areas are defined as having a population of less than 3,000 people, and with a drive time of over 60 minutes to a settlement of 10,000 or more.
} 
The first category (Type One) comprises those islands large enough to sustain a national multiple presence and due to their size, accommodate a variety of organisational forms (convenience stores, supermarkets and superstore) and fascias. Typically these islands have both an urban and rural catchment area as well as a number of independent retail operators. Whilst having a population that can support some form of retail provision, a number of smaller islands around the Scottish coast have no national multiples and are serviced by one or more independent operators, a community group or a social enterprise (Type Two). These businesses often sustain smaller, more dispersed island communities and may occupy multiple roles (Byrom et al 2001). Finally, despite having a permanent population, a small number of Scottish islands have no retail presence. These communities rely upon products being ordered and transported by boat from the larger islands or the mainland (Type Three). By providing this categorisation, the research will examine whether consumer empowerment is influenced by different levels of retail accessibility.

The research itself was divided into two stages and adhered to all necessary ethical procedures. The first phase involved a quantitative survey that explored the consumption patterns of island residents. The aim was to understand the impact of e-commerce upon respondents shopping behaviour and lifestyle activities. For each of the three research locations the drive time from the primary urban centre was first mapped ${ }^{8}$ and questionnaires allocated according to the approximate population of each catchment. Households within the drive time area were then randomly selected and provided with a self-completing postal questionnaire. Altogether 2077 questionnaires were distributed to resident households across

\footnotetext{
${ }^{8}$ Drive Time definitions were: Urban; 10 - 20 mins; 21 - 30 mins; 31 - 60 mins; $60+$ mins.
} 
the three island types (Table Two). In order to identify any spatial patterns in e-shopping, questionnaires were distributed at varying distances to the main town (due to the physical size of Type Two and Three locations, this exercise was limited to Type One islands). Where possible, questionnaires were distributed at the mid-point in each category (for example at the 15 minute point in the 10 minute - 20 minute category). However, in some of the more remote island locations, communities were dispersed over a broader area and as a consequence, the drive times were expanded towards the boundaries of the defined category. In addition, no Type Two islands were surveyed on the Outer Hebrides. Although islands such as Scalpay and Great Bernera were previously separated from the main island, these are now connected by causeways that allow vehicle access and therefore do not fit the research criteria. All data were coded and analysed using SPSS.

For the second phase of the research, a series of semi structured qualitative interviews were held with respondents who had participated in the previous stage. These interviews used the quantitative findings to explore whether e-commerce had redressed the imbalances that impeded consumer empowerment on the Scottish islands. Each individual narrated their own personal shopping experiences and expanded upon issues identified in the first phase of the research. Altogether 39 persons were interviewed with over 19 hours of qualitative research material being recorded (Table Two). On Type One islands, respondents from each of the five drive time categories were interviewed. All interviews were conducted by telephone and data were subsequently transcribed and analysed with key themes being identified through the use of established content techniques (Hsieh and Shannon 2005).

Table Two about here 
This research has a number of limitations. First, no attempt is made to differentiate between the island groups. The three locations are viewed homogenously. As a consequence, any inter-island differences are not detailed or discussed (Currie et al., 2019). Secondly, the research was conducted during the late Summer / early Autumn and does not consider whether responses would differ during other times of the year. Finally, although the response rate from this research (19\%) falls within the 10\% - 40\% levels expected from a general population survey (Cao 2012), Draugalis and Plaza (2009) note that to minimise non response error, a return rate of between $50 \%-60 \%$ is optimal. As a consequence, this survey sample may not be representative of the target population and the conclusions drawn may not necessarily be applicable to other island groups.

\section{Findings from the Scottish Isles}

Altogether 396 responses were received by the closing date of which 388 were usable (Table Three).

Table Three about here

The research identified that broadband provision on the islands was widespread and that internet usage amongst respondents was high with $95 \%(\mathrm{n}=351)$ maintaining that they had on-line access and 92\% $(n=341)$ having a broadband connection. Only $23 \%$ of respondents stated that internet availability had not influenced the way in which they shopped while just over $6 \%$ stated that they had not purchased any products on-line over the past four weeks. 
An Exploratory Factor Analysis (EFA) (Table Four) was then conducted to identify whether the constructs of behavioural change identified amongst island residents, reflected theoretical conceptualisations of consumer empowerment. Initially 18 items were subject to an EFA with varimax rotation. The Kaiser-Meyer-Olkin (KMO) measure of sampling adequacy had a value of .913 and the Bartlett's test of sphericity was significant at the .000 level. Kaiser and Rice (1974) recommended accepting KMO values greater than 0.5 while the significance of the Bartlett test confirms that relationships exist between variables. It was therefore possible to conclude that factor analysis was appropriate for these data. Osborne and Costello (2009) suggest that if an item has a communality of less than .4 it may not be related to the other items and should be dropped. One item was therefore removed after the initial analysis and the procedure repeated. This provided a mean communality of .616.

The minimum loading for an item was .32 as recommended by Tabachnick and Fidell (2001) with crossloading items being acknowledged in the table. Stevens (1986) recommends the use of eigenvalues-one criterion when less than 30 variables are being used, over 250 observations are made and the mean commonality is greater or equal to .60 . Osborne and Costello (2009) also note that a factor with fewer than three items is considered weak and unstable. These criterion were met and four components with eigenvalues greater than one were extracted and accounted for $62 \%$ of the variance. A scree test further suggested that each of these components were meaningful.

\section{Table Four about here}

The variables included in Factor One appear to relate to the information benefits provided through internet connectivity. Previous research noted that island residents often had limited 
access to product and sales information and were heavily reliant upon local communications (Byrom et al., 2001, 2003). The findings suggest that respondents use the internet to overcome this limitation and to better inform their retail decision making. This first factor was therefore labelled Information Provision. The difficulties associated with island travel have been well documented and these problems are further compounded if individuals are reliant upon public transport (Scottish Government, 2008; 2016). Factor Two relates primarily to these issues and was labelled Travel and Public Transport. Prior to e-shopping, many island residents were limited in their ability to pursue hobbies and interests due to a lack of specialist providers as well as constraints upon time. Factor Three reinforces previous research that identified how the internet has reconfigured traditional patterns of social and domestic activity (Couclelis 2000) and was labelled Control over budgets, promotions and work life balance. Factor Four not only suggests that consumers continue to make impulse purchases but also serves to highlight the limitations to consumer empowerment. Despite the competitive threat of the internet, local retailers appear reluctant to negotiate over price. Moreover, the ability of e-commerce to reduce the time spent on domestic activities also appears limited.

The four constructs provided in Table Two were subsequently used to inform the qualitative phase of the research. Initially residents were asked to comment upon the islands existing retail offer before considering whether improved information provision, a reduced reliance upon public transport and greater budgetary control had redressed the power imbalance inherent within existing buyer - seller relationships. The research also explored whether the islands infrastructure or the actions of the retailers themselves acted as a barrier to greater consumer emancipation. 
The findings confirmed previous research and identified limitations in the islands physical retail provision (Marshall et al., 2018). One primary reason for this was the basic mix of retail shops in the town centre. For example:

"I don't do a lot of shopping in the town centre now...... If I knew they had the shops, and if they had the things I wanted I would get them. I definitely would shop in Lerwick because for my work I am in the town centre twice a week anyway.... I would never buy clothes on Shetland for my daughter as they never have anything that fit her and the clothes that they have are horrendous. They never seem to have anything nice..." (Aimee, Working Mother with three children, Shetland Islands, Type 1, 21 30 minutes travel time to town centre)

Similarly:

"The shops in the town can't necessarily carry the size of stock for me to be able to go in to say my bed is broken and for them to say here is a replacement, that day. It might take two or three weeks. Now I am buying that on the internet, at something like a third of the price that I would be able to get it in town and that is including it being posted, well delivered up to me by courier." (Elizabeth, Crofter, Western Isles, Type 1, 31-60 minutes travel time to town centre).

Such views suggest that respondents were not only discontent with the price of products but also other factors such as quality and fashion also remained an issue. However, due to the limited choice available locally, residents often felt compelled to accept what was available.

While some retailers were identified as offering exemplary levels of customer service, many others were criticised for their poor attitude and unwillingness to respond to local needs. This it was argued, stemmed from entrenched views and a feeling that "it has always been done this way". For example:

"I could tell you lots of stories like that about local retailers. They all complain that people internet shop but when you go in there to buy something, say for slippers they will say och this is the wrong time of year to buy. Says who? says you, I am the customer. I want slippers, what are you telling me? It is the wrong time of year to buy. I have been there so many times for children's shoes and I have been told, you've 
come in too late. They are all gone. What are you talking about? So when are they next lot coming in? And they seem to be quite entrenched in their ordering. Well I don't know whether that is the suppliers or is it just the way they have always done it and they can't change." (Catherine, Working Housewife, Western Isles, Type 1, 60+ minutes drive time).

Respondent attitudes toward e-commerce were therefore mediated by a general discontent with the existing retail provision, an ambivalence toward the level of customer service provided and a realisation that consumer sovereignty was limited by existing power hierarchies.

\section{Factor One: Information Provision}

The internet allows individuals to participate in consumption activity in a low cost, instantaneous and largely unregulated manner. Perhaps unsurprisingly therefore, access to consumer and product related information was identified as one of the primary benefits stemming from on-line connectivity. While there was an acknowledgement that broadband speeds were relatively slow in the more rural areas (Philip et al., 2017), this concern was balanced against the benefits that stemmed from having access a range of previously unavailable information sources. For example:

“..... if I need to find out anything I'll just immediately go online because I know I'll get the information fast and up to date.. My laptop is always on. Not for shopping necessarily but you know, for the different things I do. I look at things like moneysupermarket and stuff if I want to find out about different savings products or financial things I will have a look on there as it is difficult to get that sort of information." (Lorna, Volunteer, Orkney, Type 1, 21-30 minutes drive time from town centre).

In the context of consumer empowerment, this democratisation of information represents a mechanism for challenging inherent power asymmetries (Allen 2008). By offering a means to reassess existing buyer - supplier relationships, individuals may stimulate change through a process of realisation and reflection. While from a liberationist perspective such 
transformations are predicated upon the authority of the collective voice, Lankes (2008) noted the concerns that revolved around the credibility of on-line sources. This research found no evidence to suggest that individuals questioned the legitimacy of information that guided their decision making, on-line sources were seen as both authentic and authoritative (Fuller et al, 2009; Shankar et al., 2006).

Indeed in one interview, the respondent considered on-line information to be more influential than traditional channels. As he noted:

"I would search using google and reviews, I don't use anything like Which magazine as I have found them unreliable but actually I use Amazon. I do buy from Amazon sometimes but I find that Amazon's feedback from customers is pretty straight forward and quite good"(Mike, Retired, Orkney, Type 3, 60+ minutes travel time to town centre).

While internet availability provides opportunities for realisation and reflection, the ability to also undertake action remains fundamental to liberationist thinking. The research therefore sought to explore the extent to which the decentralisation of authority that stemmed from greater information provision influenced the behaviour of island residents. While some respondents continued to include local retailers in the decision making process, these businesses were now required to compete against national and international providers. For example:

"I look in the Hydro shop in Kirkwall as they have special offers but we know that Orkney Television don't compete whatsoever on price. It could be a hundred or two hundred pounds dearer." (Mike, Retired, Orkney, Type 3, 66 minutes travel time to town centre).

\section{Similarly}

"..Shopping on the internet is just more flexible, I find the price up in Kirkwall and then go online and find out what alternatives there are. It gives more choice. Well shopping in Kirkwall is very limited. I would look online for furniture even tools and all that sort of thing.. for clothing there is a wider choice than what is available in Orkney." (Irene, Retail Manager, Orkney, Type 121-30 minutes travel time to town centre). 
In addition to individual action, the research identified how internet availability afforded opportunities for collective activity. For example, one group of island residents had sought to challenge the dominant power logic through greater communal participation. E-commerce was used to bulk purchase a commodity product (pet food) which was subsequently distributed amongst local residents. This form of disintermediation was derived directly from the shared experiences of individual consumers and sought to challenge established buyersupplier relationships. Such reflective strategies represented a form of 'conscientization' as individuals sought to alleviate their societal position through collective action.

\section{Factor Two: Travel and Public Transport}

From a liberationist perspective, consumer empowerment and wider social transformation are predicated upon the ability of individuals overcome structural market impediments.

Deficiencies in the transport infrastructure, as well we higher rates of fuel poverty ${ }^{9}$ have been identified as having a negative impact upon consumption practices in the Scottish isles (Baker et al., 2016; Freathy and Calderwood, 2016; Scottish Government, 2008). Ecommerce was identified as a means of overcoming these limitations and challenging the inequalities perpetuated by an inadequate transport system. As one respondent noted:

"If you want say nails or screws or something like that you can go round half a dozen places in the town and not find them and basically find that no one in Orkney has just what you want,.. whereas you can probably click on eBay and find it in a few seconds. " (Sarah, Part-time employee, Orkney, Type 1, 10-20 minutes travel time to town centre).

\footnotetext{
${ }^{9}$ Fuel poverty exists when a household, in order to maintain a satisfactory heating regime is required to spend more than $10 \%$ of its income (including Housing Benefit or Income Support for Mortgage Interest) on all household fuel (The Scottish Executive Fuel Poverty the Scottish Fuel Poverty Statement 2002).
} 
The research however suggested that, in addition to convenience, a reconfiguration of mobility patterns also helped reduce some of the constraints associated with the domestic division of labour. For example:

"I now only go into town say once a fortnight or once a week if I really have to, I may not get all the jobs done. It takes me over an hour to drive to town and I have to be back here for half past three for my youngest daughter coming home from school. If you have a number of places to visit such as the vets, it isn't easy to get to or easy to park. So it is far easier for me to order on-line their medicines and so on for fleas and ticks and ear mites, grooming brushes and things like that." (Catherine, Working Housewife, Western Isles, Type 1, 60+ minutes travel time).

In addition to offering residents greater control over their own personal circumstances, the ability to shop without having to travel had translated into direct financial savings for many island residents. For example:

"I now make fewer town centre shopping trips - why? Economics. Cash. Everything is so expensive, especially fuel.... The fuel is so expensive and it's just not having that extra cash either. To fill up my car I can't afford it ...I put in $\$ 50$ to fill it up" (Catherine, Working housewife, Western Isles, Type 1, 60+ minutes drive time).

For those individuals who lived on the smaller islands and required a ferry journey to the main town, the savings could be even more significant.

"I paid $£ 38$ to get my car to Kirkwall and back the other day so even a fairly high carriage charge is obviated when you have all that to pay. And on top of that, there is my fare and if my wife comes with me, there is her fare as well, you are into $£ 60$ or more just to get to Kirkwall ...." (Duncan, Semi-retired, Orkney, Type 2, 1 hour 46 minutes travel time to town centre).

The findings also suggest that e-commerce could help emancipate those island residents whose economic freedoms were impaired through physical disability. For example, Kathleen a partially sighted Shetland resident noted that she had found it difficult to use public transport and that retailers in town were not particularly sympathetic to her needs. As a consequence, she limited her visits to just a few shops where she felt comfortable. The 
obvious disadvantage of this was the restriction on choice and variety. Although she continued to travel into the town in order to visit the bank or the chemist, e-commerce now provided an opportunity to purchase a broader array of products in a relatively relaxed, unpressured environment. As she noted:

"most shopping is done on-line nowadays, pricewise things online are much cheaper and the likes of Amazon and John Lewis, they deliver to Shetland for free. My husband reads to me whatever is on-line, we order it and it is delivered right to the door, we don't have to go anywhere." (Kathleen, Retired, Shetland Islands, Type 1, 21-30 minutes travel time to town centre).

Factor Three: Control over budgets, promotions and work life balance

Human liberation theory recognises that disempowerment may manifest itself in a variety of forms. While this may include political or economic injustice, social inequality also occurs when individuals do not have control over their own personal circumstances (Rappaport, 1987). The findings suggest that e-commerce has helped some residents redress a work / life balance and achieve personal freedoms consistent with liberationist theories of empowerment. For example, respondents stated that they now undertook shopping 'as and when it is suitable for me' (Derek, Self Employed, Orkney, Type 1, Urban resident) and 'whenever there is a gap in my world'. (Val, Retired, Orkney, Type 2, 120 minutes travel time to town centre). Moreover, the flexibility afforded by on-line provision allowed consumers to pursue alternative hobbies and interests. As one resident commented:

"We no longer have to travel into town as much as before.. I think I would rather mess about in my garden than bother in shops. I don't like shopping ..." (Sarah, Parttime employee, Orkney, Type 1, 10-20 minutes travel time to town centre).

At the same time, e-commerce was identified as having a more profound, transformational effect upon the lifestyle of island residents. For example, trips to the mainland traditionally 
entailed individuals purchasing products they anticipated they would need over the next six / twelve months. As one respondent explained:

"We did not shop, we raided the stores. You have so little time and there are so many things that you needed. You had to know what you were doing and what you wanted. We just spent a fortune stocking up" (Annabel, Part-time employee with two children, Western Isles, Type 1, 60+ minutes travel time to town centre).

Respondents noted that shopping in this manner would often impact upon cash flow, result in unnecessary purchases and lead to concerns over budgets and household spending. School wear bought on a mainland trip six months earlier was frequently the wrong size or no longer required. Although there were opportunities to swap and trade items locally, this system was not popular and not considered particularly efficient. In contrast, e-commerce now allowed individuals to spread purchases across the calendar year and co-ordinate their spending with on-line sales.

While individuals still periodically travelled off the island, these excursions reflected a form of consumer emancipation derived through the enabling effects of e-commerce. While trips still involved visits to retail stores they tended to revolve around more leisure based activities. As one individual commented:

"When we travel to the mainland we have more time to visit friends and see a show... I still like to go to John Lewis to see what is available and we always end up spending too much.... The trips these days are less pressured, you no longer have a long list of things you must buy and bring back..." (Billie, Retired, Western Isles, Type 1, 60+ minutes travel time to town centre)

Similarly:

"My daughters come back from the mainland with suitcases full of stuff, ..because Primark is so cheap they will buy five things rather than just one. The free boat trips and lack of any limits on what you bring back encourages them to go mad." (Aimee Working Mum with three children Shetland Islands, Type 1, 21 - 30 minutes travel time to town centre) 
While shopping could still result in overspending, reconfiguring the purpose of mainland visits redresses a structural market failing. By alleviating the requirement to purchase essential items, e-commerce represents an empowering mechanism that allows island residents to reassert control over an impediment that has traditionally mediated their own existence.

\section{Factor Four: Limitations to consumer empowerment}

While a key element of human liberation theory is the ability to challenge the asymmetry that characterises buyer - seller relations, it is erroneous to suggest that e-commerce represents a mechanism through which power simply transits from retailer to consumer. Those who assert influence remain unlikely to willingly surrender or relinquish their advantaged position (Anderson 1996).

The research identified a number of factors that prevented consumers from asserting greater economic leverage in the market exchange process. While the option to buy on-line offered greater consumer choice, a number of mainland retailers either refused to deliver to the islands or (despite RET) levied unacceptably high transportation charges. For example:

"Getting delivery to Whalsay is a problem. A lot of products have free postage in the UK but don't offer the same service to Shetland. Some websites let you go through the whole process then state they do not deliver to the islands..... Other retailers will deliver once then not accept an order another time." (Andrew, Offshore Worker, Type 2, 1 hour 48 minutes travel time to town centre)

In such cases the opportunity to challenge existing buyer-supplier relationships are negated and residents left with little alternative other than to use local provision. 
Some stores such as those selling short shelf life products also remained relatively unaffected by on-line competition. As one Hebridean respondent noted:

"The local shop and post office has gone down and down. It has very little in it.. The post office bit is only open in the mornings and they have literally got hardly anything you would buy, ... but if you want things like paracetamol and newspapers you, have to use them...." (Ursula, Retired, Western Isles, Type 1, 10-20 minutes travel time to town centre).

Similarly, respondents were often compelled to use local retailers for unplanned / distress purchases. One respondent commented that people only replaced electrical items when their existing ones fail. She had recently bought a washing machine from a local provider and noted:

"I have bought a microwave on-line because I could do a comparison, however when your washing machine goes and you have a big family, you need one fairly rapidly." (Laura, Single mum with young daughter, Shetland isles, Type $160+$ minutes travel time to town centre)

The findings therefore suggest that the impact of e-commerce may have had a variable effect upon the commercial activities of island retailers. As a consequence, the opportunities to challenge existing power hierarchies and assert consumer sovereignty appear to be mediated by the type of retailer type and the products sold.

Despite having a positive impact upon consumer mobility, the research also identified that for many island residents, travel patterns remained largely unaffected by e-commerce. This was primarily due to the concentration of grocery supermarkets in the main towns. Individuals living in more rural locations were particularly disadvantaged by this spatial disparity and were often reliant upon local stores. The research noted that respondents were often reluctant to use this provision for anything other than top up shopping. While recognising the 
importance of such businesses to the community, local shops were considered expensive. For example:

"I try to shop locally .... I appreciate that markup is important and you have to make a profit ....... I know that they are trying create local employment but the shop is overcharging, way over-charging when in fact they should looking at how they are running themselves because they are so over staffed it is unbelievable. You know they have got three people when there is only one customer. ...The van shops still come round, but the butchers are overcharging, the bakers do quite nicely with the price they charge.." (Elizabeth, Crofter, Western Isles, Type 1, 31-60 minutes travel time to town centre).

Other respondents were more critical of the services provided locally.

"The local post office, a mile away has got a little shop attached to it, basic groceries ..... It is unbelievably filthy.... I think these little shops, what keeps you going is the income from the post office. It has a few loaves of stale bread, the chap he's got a fishing boat and sticks a tray of mackerel down next to the grocery counter. He has a few tins of beans, a few tins of soup like and things like that." (Chris, Retired living alone, Western Isles, Type 1, 10-20 minutes travel time)

While some residents used mobile stores or on-line sites such as Amazon Subscribe, the product range was either too limited or restricted to more expensive, non-essential items. Many island residents therefore continued to travel into the main towns in order to undertake their primary shop. For example:

"We do our basic shopping once a week in Kirkwall, we don't shop in Stromness which is nearest to us because the big stores, Lidl and Tesco are in Kirkwall..." (Mike, Retired, Orkney, Type 3,60+ minutes travel time to town centre).

Similarly:

"We do our grocery shopping in the two supermarkets [in the main town] as we are not comfortable with what is available locally...... if you want vegetables generally you have to go the Co-op or Tesco, so we very much do all of our shopping in either of those two stores... (Sally, Mother with toddler, Shetland Isles, Type 1, 10-20 minutes travel time to town centre)

Residents who travelled to shop in the main town either used their own car, shared lifts with family and friends or were forced to rely upon the public transport system. The inadequacies 
of the latter was highlighted by one Shetland resident (living just over 20 miles away from the main town) who had access to only one bus a day that left at 0800 each morning and returned at 1700 .

\section{Conclusions}

By exploring the transformational effects of e-commerce from a liberationist perspective, this paper has sought to adopt a broad holistic interpretation of consumer empowerment. While numerous studies have highlighted how the internet offers greater access to information, provides alternative sources of authority and contributes to strategic co-creation, liberation theory would suggest that such activities in themselves do not necessarily equate with greater consumer emancipation.

As the Scottish islands illustrate, deficiencies in the transport infrastructure, spatial disparities in grocery provision and the strategies of mainland retailers all represent forms of market impediment that serve to reinforce the dominant power logic. The opportunity for ecommerce to act as a catalyst for greater self-determination and social transformation is therefore mediated by external constructs that preserve established power asymmetries. While internet access may have allowed some island residents to reconfigure the exchange relationship, empowerment in the form of greater financial autonomy, fewer domestic activities and increased leisure time, will continue to remain limited until these broader infrastructural failings are addressed.

While market impediments may limit the impact of consumer empowerment, e-commerce does represent a mechanism for shared conscientization. The migration from a physical to an 
online shopping environment suggests that the internet represents an opportunity for "virtual" mobilisation where the collective voice is not necessarily a co-ordinated or managed act. While communal participation was in evidence, established hierarchies may be challenged without the requirement of consumers to interact or even communicate with each other.

In conclusion, liberation theory considers inequality and injustice to be the outcome of institutional and market failings that are maintained through established power hierarchies. By placing empowerment within this broader, conceptual framework, the research has identified those factors that mediate and impede wider consumer emancipation. While ecommerce may have helped redress imbalances in the exchange relationship, greater social and economic freedoms in the Scottish isles will continue to remain limited until these infrastructural and competitive deficiencies are addressed. 


\section{References}

Allen, J. (2008). The Intersection of Liberation Theology, Structural Social Work, and Empowerment Practice, paper presented at the Third North American Conference on Spirituality and Social Work, Fredericton, New Brunswick, Canada.

Armstrong, H., Johnes, G. and McBean, A. (1991). Consumer Goods and Energy Prices on the Isle of Man, Management Research News 14(7), 31-35.

Anderson, J. (1996). "Yes, but is it empowerment? Initiation, implementation and outcomes of community action", in Humphries, B. (Ed.), Critical Perspectives on Empowerment, Venture Press, Birmingham, pp. 69-83.

Baker, K.J., Mould, R., \& Restrick, S., (2016), Proiseact Spéird - The Spéird Project: Understanding influences on fuel poverty in rural and island Scotland. Final report for the Eaga Charitable Trust,

Black, I and Veloutsou, C. (2017), Working consumers: Co-creation of brand identity, consumer identity and brand community identity, Journal of Business Research, 70, 416-429.

Byrom, J., Medway, D. and Warnaby, G. (2003). Strategic alternatives for small retail businesses in rural areas, Management Research News, 26(7), 33-49.

Byrom, J., Medway, D. and Warnaby, G. (2001). Issues of provision and "remoteness" in rural food retailing: A case study of the Southern Western Isles of Scotland, British Food Journal, 103(6), 400-413.

Calderwood, E. and, Freathy P. (2011). Challenges in the supply of perishable products to island communities, The International Review of Retail, Distribution and Consumer Research, 21(2), 145 - 160.

Cao, X. (2012). The relationships between e-shopping and store shopping in the shopping process of search goods, Transportation Research Part A: Policy and Practice, 46(7), 9931002 .

Carnegie UK (2008). 'Bearing Fruit- Good Practice in asset-based rural community development', Development Trusts Association, Carnegie Trust UK, Dunfermline.

Carnegie UK (2007). 'A Charter for Rural Communities- The final report of the Carnegie Commission for Rural Community Development', Carnegie Trust UK, Dunfermline.

Celis, L. (2016) The Legacy of Liberation Theology in Colombia The Defense of Life and Territory, Latin American Perspectives, Vol. 43 No. 3, May 2016, 69-84

Cherayi, S. and Jose, J. (2016) Empowerment and social inclusion of Muslim women: Towards a new conceptual model, Journal of Rural Studies 45 pp. 243-251

DOI:10.1016/j.jrurstud.2016.04.003 
Christodoulides, G. (2009) Branding in the post-internet era Marketing Theory, 9 (1), pp. 141-144.

Clarke, I. (2000) "Retail power, competition and local consumer choice in the UK grocery sector", European Journal of Marketing, 34 (8), pp.975-1002, doi: 10.1108/03090560010331469

Copus, A. and Crabtree, B. (1992). Mapping Economic Fragility: an Assessment of the Objective 5b Boundaries in Scotland, Journal of Rural Studies, 8(3), 309-322.

Copus, A. and Hopkins, J. (2018) Demographic change in the Sparsely Populated Areas of Scotland (1991-2046), Demographic change in remote areas: Research Note 2: The James Hutton Institute, available at: https://www.hutton.ac.uk/sites/default/files/files/research/srp201621/RD3.4.1\%20Note\%20WP1-3\%20web\%20-\%20published.pdf

Couclelis, H. (2000). From sustainable transportation to sustainable accessibility: can we avoid a new tragedy of the commons? In Janelle, D. and Hodge, D., (eds.) Information, Place, and Cyberspace: issues in accessibility. Berlin: Springer-verlag pp. 342-356.

Currie M, Pinker A and Copus A (2019) Strengthening Communities on the Isle of Lewis in the Western Isles, United Kingdom. RELOCAL Case Study $N^{\circ}$ 33/33. Joensuu: University of Eastern Finland.

De Bernardi, P. and Tirabeni, L. (2018), Alternative food networks: sustainable business models for anti-consumption food cultures, British Food Journal, 120 (8), pp. 1776-1791.

Denegri-Knott, J., Zwick, D. and Schroeder, J. (2006). Mapping consumer power: an integrative framework for marketing and consumer research, European Journal of Marketing 40(9/10), 950-971.

Draugalis, J. and Plaza, C. (2009). Best Practices for Survey Research Reports Revisited: Implications of Target Population, Probability Sampling, and Response Rate, American Journal of Pharmaceutical Education, 73(8), p.142.

Evans, E. (1992) Liberation theology, empowerment theory and social work practice with the oppressed, International Social Work Vol. 35 pp. 135 - 147.

Fischer, A. and McKee, A. (2017) A question of capacities? Community resilience and empowerment between assets, abilities and relationships Journal of Rural Studies, 54 pp.187197

Freathy, P. and Calderwood, E. (2013). The impact of Internet adoption upon the shopping behaviour of island residents, Journal of Retailing and Consumer Services 20(1), 111-119.

Freathy, P. and Calderwood, E. (2016). Coping with Change: The Implications of eCommerce Adoption for Island Consumers, Regional Studies, 50 (5), pp. 894-908.

Füller, J., Mühlbacher, H., Matzler, K. and Jawecki G. (2009). Consumer Empowerment Through Internet-Based Co-creation, Journal of Management Information Systems, 26(3), pp. 71-102. 
Guirado, C., Valldeperas, N., Tulla, A., Sendra, L., Badia, A., Evard, C., Cebollada, A., Espluga, J,. Pallarès, I., and Vera, A. (2017) Social farming in Catalonia: Rural local development, employment opportunities and empowerment for people at risk of social exclusion, Journal of Rural Studies, 56, pp.180-197.

Gutiérrez, G (1988). A Theology of Liberation: History, Politics, and Salvation, New York, Ortis Books.

Harrison, T., Waite, K. and Hunter, G. (2006). The internet, information and Empowerment, European Journal of Marketing, 40 (9/10), 972-993.

Hopkins, J. And Copus, A. (2018). Definitions, measurement approaches and typologies of rural areas and small towns: a review, James Hutton Institute available at: https://www.sruc.ac.uk/download/downloads/id/3810/342_definitions_measurement_approac hes_and_typologies_of_rural_areas_and_small_towns_a_review.pdf

Hsieh, H-F. and Shannon, S. (2005). Three Approaches to Qualitative Content Analysis, Qualitative Health Research, 15 (9), 1277-1288.

Karimi, J. and Walter, Z. (2015) The role of dynamic capabilities in responding to digital disruption: a factor-based study of the newspaper industry, Journal of Management Information Systems, 32, pp. 39-81, 10.1080/07421222.2015.1029380

Kaiser, H.F. and Rice, J. (1974). Little Jiffy, Mark IV, Educational and Psychological Measurement, 34, 111-117.

Kleinert, E., Beale, G., Henderson, N. and Davidson, N. (2018), Understanding the Scottish Rural Economy, Agriculture and Rural Economy Directorate, Scottish Government.

Laird, J. and Mackie, P. (2009). Review of Economic Assessment in Rural Transport Appraisal, Transport Research Series, Edinburgh, Scottish Government.

Lankes, D. (2008). Credibility on the internet: shifting from authority to reliability, Journal of Documentation, 64(5), 667-686.

Lee, G., Beomcheol Kim. P. and Perdue. R. (2016). A longitudinal analysis of an accelerating effect of empowerment on job satisfaction: Customer-contact vs. non-customer-contact workers, International Journal of Hospitality Management, 57, Pages 1-8. doi.org/10.1016/j.ijhm.2016.05.006

Lemire, M. (2010). What can be expected of information and communication technologies in terms of patient empowerment in health?, Journal of Health Organization and Management, 24(2), $167-181$.

Levine, D. (1988) Assessing the Impacts of Liberation Theology in Latin America, The Review of Politics, 50 (2) :241 - 263

Lindridge, A. Peñaloza, L. and Worlu, O. (2016) "Agency and empowerment in consumption in relation to a patriarchal bargain: The case of Nigerian immigrant women in the UK",European Journal of Marketing, 50 (9/10), 1652-1671, doi: 10.1108/EJM-07-2011-0365 
London Economics (1997), Competition in Retailing, Research Paper 13, Office of Fair Trading, London.

Macdonald and Uncles, M. (2007). Consumer savvy: conceptualisation and measurement, Journal of Marketing Management, 23(5-6), 497-517.

Marshall, D., Dawson, J. and Nisbet, L. (2018): Food access

in remote rural places: consumer accounts of food shopping, Regional Studies, 52(1) 133144.

DOI:10.1080/00343404.2016.1275539

McKee, A. (2015) Legitimising the Laird? Communicative Action and the role of private landowner and community engagement in rural sustainability, Journal of Rural Studies, 41 pp. $23-36$.

Moufahim, M., Wells, V. and Canniford, R. (2018) The consumption, politics and transformation of community, Journal of Marketing Management, 34:7-8, 557-568, DOI: 10.1080/0267257X.2018.1479506

Neghina, C., Caniëls, J., C., Bloemer, M. and van Birgelen, M. (2014) Value co-creation in service interactions: Dimensions and antecedents, Marketing Theory, 15, (2) pp. 221-242.

Niininen, O., Buhalis, D. and March, R. (2007). Customer empowerment in tourism through consumer centric marketing (CCM), Qualitative Market Research: An International Journal, 10(3), $265-281$.

OFT (2012). Price and choice in remote communities: Call for Evidence, OFT Report 1420, Office of Fair Trading, London.

https://webarchive.nationalarchives.gov.uk/20140402202637/http://www.oft.gov.uk/shared_o $\mathrm{ft} /$ consultations/remote-communities/OFT1420.pdf Last accessed 8th November 2019.

Osborne, J. and Costello, A. (2009). Best Practices in Exploratory Factor Analysis: Four recommendations for getting the most from your analysis, Pan Pacific Management Review, 12(2), 131-146.

Philip, L., Cottrill, C., Farrington, J., Williams, F. and Ashmore, F. (2017) The digital divide: Patterns, policy and scenarios for connecting the 'final few' in rural communities across Great Britain, Journal of Rural Studies, 54, 386-398.

Pires, G., Stanton, J. and Rita, P. (2006). The internet, consumer empowerment and marketing strategies, European Journal of Marketing, 40(9/10), 936-949.

Rapp, A., Ahearne, M., Mathieu, J. and Rapp, T (2010). Managing sales teams in a virtual environment, International Journal of Research in Marketing, 27(3), pp.213-224.

Rappaport, J. (1987) 'Terms of Empowerment-Exemplars of Prevention: Toward a Theory for Community Psychology', American Journal of Community Psychology 15(2): 121-45.

SAC (2012). Rural Scotland in Focus, Rural Policy Centre, Scottish Agricultural College. 
Saren, M. (2011). Marketing empowerment and exclusion in the information age, Marketing Intelligence \& Planning, 29 (1), 39-48.

Schembri, S. and Latimer, L. (2016): Online brand communities: constructing and coconstructing brand culture, Journal of Marketing Management, 32 (7-8) pp. 628 - 651. DOI:10.1080/0267257X.2015.1117518

Schiffling,S., Karamperidis, S. and Nelson, J. (2015) Local Shops vs. Online Retailers: Competition or Synergy?, Scottish Geographical Journal, 131:3-4, 220-227.

DOI: $10.1080 / 14702541.2014 .978805$

Scottish Government (2008). Highlands \& Islands Scotland: European Regional Development Fund 2007-2013 structural funds operational programme, Edinburgh, Scottish Government.

Scottish Government (2010). Socio-Economic Briefing on Rural Scotland: Identifying Fragile Rural Areas Paper 5 Supporting Evidence Provided to the Rural Development Council Working Group, Crown Copyright, available at: http://www.scotland.gov.uk/Resource/Doc/320175/0102396.pdf last accessed 8th November 2019.

Scottish Government (2016). Ensuring that Markets Work Well for Businesses and Consumers - A Strategic Assessment of Markets in Scotland, Crown Copyright, available at: http://www.gov.scot/Publications/2016/06/5280

Scottish Government (2018). Scottish Government Urban Rural Classification available at: https://www.gov.scot/publications/scottish-government-urban-rural-classification2016/pages/2/

Shankar, A., Cherrier, H. and Canniford, R. (2006). Consumer empowerment: a Foucauldian interpretation, European Journal of Marketing, 40, (9/10), 1013-1030.

Sherover-Marcuse R. (2003). Liberation Theory: Axioms and Working Assumptions about the Perpetuation of Social Oppression. In N.G. Yuen (ed) The Politics of Liberation: An American Studies Reader, 4th Edition, Dubuque, IA: Kendall/Hunt Publishing.

Shetland Islands Council (2004). Shetland Islands Shopping Survey 2003, Shetlands Islands Council.

Simintiras, A., Watkins, A. Ifie' K. \& Georgakas, K. (2012). Individual and contextual influences on the affective commitment of retail salespeople, Journal of Marketing Management, 28 (11-12), 1377 - 1398.

Skerratt, S. (1999) Food availability and choice in rural Scotland: the impact of "place", British Food Journal, 101(7), 537-544.

Smith, C. (1991). The Emergence of Liberation Theology: Radical Religion and Social Movement Theory, Chicago, University of Chicago Press.

Stevens, J. (1986). Applied Multivariate Statistics for the Social Sciences, Hillsdale NJ, Lawrence Erlbaum Associates. 
Steiner, R.L. (1985), “'The nature of vertical restraints", Antitrust Bulletin, 30, pp. 143-97.

Tabachnick, B. and Fidell, L. (1996). Using Multivariate Statistics, HarperCollins, New York, NY.

Waltz, A. (2016). The women who feed us: Gender empowerment (or lack thereof) in rural Southern Brazil, Journal of Rural Studies 47 (2016) 31- 40.

Wang, J., Zhao, X. and Li, J., (2013). Group Buying: A Strategic Form of Consumer Collective, Journal of Retailing, 89(3), 338-351.

Wright, L., Newman, A. and Dennis, C. (2006). Enhancing consumer empowerment Journal of Marketing, 40(9/10), 925-935.

Yoo, J. (2017) "Customer power and frontline employee voice behavior: Mediating roles of psychological empowerment", European Journal of Marketing, 51 (1),238-256, doi: 10.1108/EJM-07-2015-0477 